Journal of Engineering and Applied Sciences 14 (Special Issue 2): 5495-5500, 2019

ISSN: 1816-949X

(C) Medwell Journals, 2019

\title{
Role of using Mobile Phone among Iraqi Farmers for Agriculture Development
}

\author{
Salih Hajem Glood, Sajad Muhil and Barakat Saad Ibrahim \\ University of Al-Muthanna, Al-Muthanna, Iraq \\ salihglood74@yahoo.com, sajadalbreki@gmail.com, ba2011sa@yahoo.com
}

\begin{abstract}
The rapid evolution of Information and Communication Technologies (ICTs) has now impacted on people's daily lives of developing countries which led to provide positive results in different sectors of the community. This study aims to investigate about the main purpose of use of mobile phones; mobile phones saved time, money and Internet use on mobile phone. The study used quantitative method by distributing 350 questionnaires to respondents in the Federations of Farm Associations (FFAs) of the Southern Region in Iraq. Besides that, the collected data was analysed using SPSS 21 Version. The findings showed that $93.6 \%$ of the respondents have own's mobile phones while $80 \%$ of the respondents use mobile phone to contact with their friends. Furthermore, it implied that $95.6 \%$ of the respondents did not contact with any agriculture officer about their crop issues. The result revealed that $96 \%$ of the respondent did not search agricultural information by mobile phone about market prices regarding their good and services. While only $3.2 \%$ of the respondents seek to search agricultural information about their crops and prices. It implied that the respondents who have education were high interested to get the agricultural information and only $0.8 \%$ of the respondents some time search agricultural information about their crops and prices. Result showed that large majority of the respondents did not use mobile phone for getting agriculture information and similarly internet not uses to get information regarding agriculture and crop prices. It need to provide awareness among farmers about proper use of mobile technologies for increase the agriculture product and increase their income by mobile phones in their working places.
\end{abstract}

Key words: Rural areas, mobile phones internet agriculture, agricultural information, ICTs, FFAs, crops, mobile phones

\section{INTRODUCTION}

Mobile phones considered as one of the main methods of communication technology in developed and developing countries. Mobile phone "is one that is portable and can be carried by an individual to (almost) any place and still satisfies the communication needs" (Amos, 2011). Similarly, Aqilah (2011) stated that mobile phone is "an electronic device used to make mobile telephone calls across a wide geographic area, served by many public cells, allowing the user to be mobile". Other hand, the development of mobile services and the increasing growth in the provision of services to the public can be seen all over the world. According to International Telecommunication Union (ITU) 2018 the number of mobile phone subscribers has reached 7.5 billion in 2016. And in 2017, it's reached to 7.8 billion which is equal $103.5 \%$ of the world's population where 6 billion mobile subscribers in developing countries only which is equal to $98.7 \%$ of global subscriptions (ITU., 2018). Figure 1 illustrates mobile cellular subscriptions per 100 Inhabitants, 2005-2017 (ITU., 2018).

Mobile technology is considered as a one of the best forms of transferring information by using voice

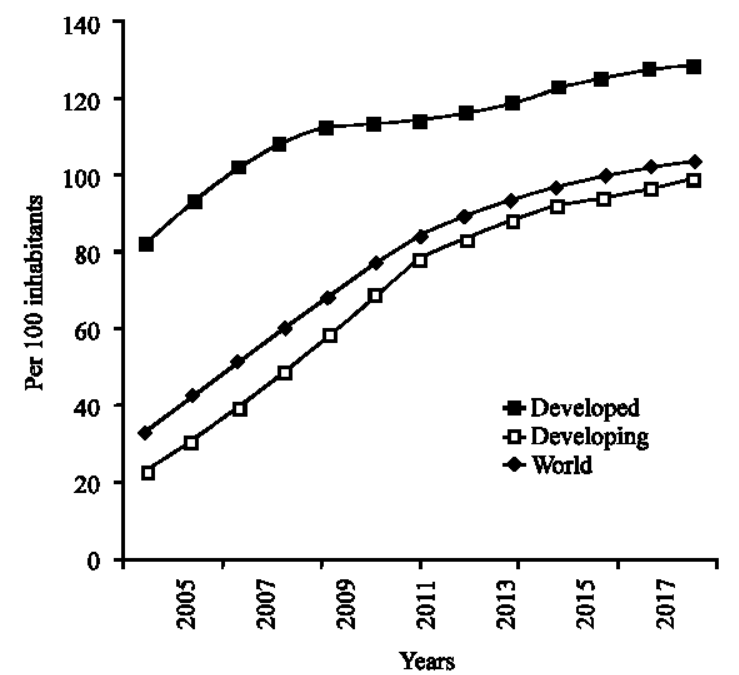

Fig. 1: Mobile cellular subscriptions per 100 inhabitants, 2005-2017 (ITU., 2018)

communications, Short Message Services (SMS) and Multimedia Message Service (MMS). Nassuora (2010) summarized the major features of the mobile devices

Corresponding Author: Salih Hajem Glood, University of Al-Muthanna, Al-Muthanna, Iraq, salihglood74@yahoo.com 
which being voice, Short Messaging Service (SMS), graphics, user-controlled operating systems, downloadable, browsers, camera functions and supporting the Global Positioning System (GPS), it has input mechanism allow the user to interact with the phone such as a keypad and touch screens in high-end smartphones today as well as use a SIM-card to allow an account to be exchanged among devices, games, PTT, memory card reader, USB, dual line support, infrared, Bluetooth and Wi-Fi connectivity (Aqilah, 2011) all features supports the capabilities and services that serve the community. In general, now a days mobile technology is increasing in developing countries day by day, now also, farmers are getting a good benefits from this in perspective of weather, a knowledge and information of crops and communication with each other's and with their families and friends.

Literature review: Information and Communication Technologies (ICT) play an important role in assisting people of different societies and improving their knowledge and information through providing new methods and techniques (such as mobile phones, telephone, computers, internet, television and radio) (Chhachhar et al., 2014). Furthermore, ICT has helped the people in different sectors of society, especially, in rural areas of developed and developing countries and given new opportunities for development in all sectors. Mobile technology is improving the quality of life of many individuals enabling convenient access to public information and services, especially, for citizens who were previously digitally excluded where the infrastructure required for internet or wired phone service is not a viable option as well as lower income level (Glood et al., 2016). The use of communication technologies by rural people have enhanced their agricultural and product. It has also, improved the capacity to provide emergency information management more effectively (Chatterjee et al., 2009; Mengistu et al., 2009). Hence, using mobile phones have a significant affected in agriculture improvement and their life (Chhachharr et al., 2014).

In the perspective of Iraq, mobile network in Iraq is strong infrastructure and suitable compared to other developing countries where the total of 10 wire and wireless communications companies which cover almost country including rural areas and there are also, a total of 8 of internet service providers (Kamil, 2012). In Iraq, the mobile subscriber's rate is reaching 30.2 million in 2016 (ITU., 2018). According to survey conducted by Younus (2014) there is a large percentage of mobile subscribers use smartphones (Fig. 2). Several applications and software was established by Iraqi Government for disseminating the information and knowledge among rural

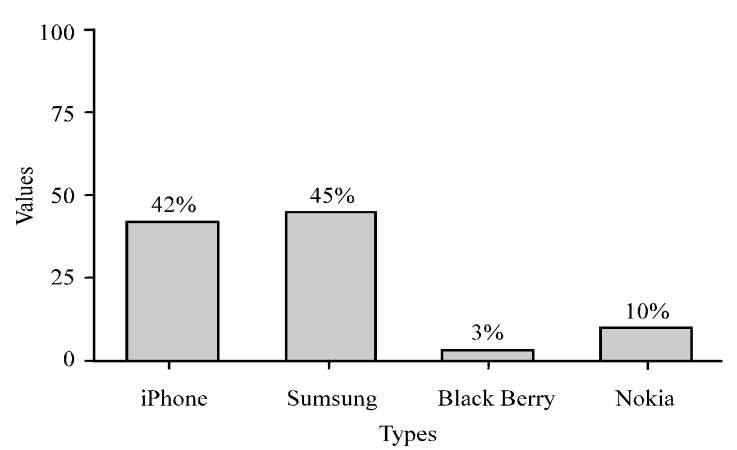

Fig. 2: Percentages and frequency about mobile types using in Iraq

people about agriculture and weather for the development of agriculture such as Weather Mobile Service (WMS) that established by Iraqi Meteorological Organization and Seismology. This application a necessary for all citizens, especially, citizens who are farmers living in rural areas in view of the recent conditions experienced by these regions. Furthermore, this application provides multiple tasks for the Iraqi farmers including: weather conditions, including information about temperature and cooler air that could potentially affect crop farming, updated information regarding Iraqi Meteorology such as weather warnings, special invitations, weather forecast notifications, news updates, inquiries and contacts with agricultural officials.

According to study was conducted in Ghana by Chhachhar and Hassan (2013) showed that farmers before using mobile phones are spent many days to sell their product in market but now mobile phone has made their life more easy to connect with customers. Furthermore, now a days, mobile phones diffusion very fast in the most of developing countries and the people are getting benefits of using this technology without any problem. Mobile phones considered as optical method in many areas of farmers to obtain the information about agriculture issues where internet services are not good in rural areas. Several studies revealed that the access of ICTs, especially, mobile technology have important effect on different sectors of people life such as poverty reduction, economic, education, income level as well as agriculture development. Therefore, using the mobile phones in rural areas of developing countries could increase farmer's efficiency. According to Bhavnani et al. (2008) indicated that the use of mobile phones among rural people in Bangladesh increased access of information and knowledge among them as well as improved their living. Furthermore, Raja et al. (2012) asserting that mobile phones provide an important service for rural farmers, 
including the provision of emergency notifications with regard to adverse weather events or changes in water or energy supply. In Malaysia and the United State, SMS is used to alert citizens when there is a decrease in drinking water or energy supplies (ITU and OECD, 2011). According to Gichamba and Lukandu (2012) SMSs have been employed in agricultural spheres to enhance farmer's interaction with their supervisors and agricultural experts. These include inquiries into the appropriate time for planting crops and weather conditions. For example, project ESoko, launched in 2009 in Rwanda, enables farmer's access the prices and type of product and agricultural commodities through SMS.

Mobile phones have provided a good opportunity to rural people, especially, to farmers to get good price and get decision about time and sell their product. Now, the use of mobile phones by farmers makes them able to sell their produce in best price or keep their product for future to sell in best price later.

Some studies such as Garnett et al. (2008); Melkers and Willoughby (2005); Pandey and Garnett (2006) have indicated that agricultural information plays a major role in farmer's development. By using mobile phones as a communication technology farmers can addressing the problems which faced them or enhancement to increase their product and incomes. Furthermore, farmers in remote areas are still facing several problems in use of ICTs due to lack of awareness and lack of infrastructure among farmers society. Most of the farmers are used old traditional methods in agriculture. Mobile phone technology has provided a good platform to farmers for sharing their knowledge and information among them such as market prices and weather information in developing countries (Munyua, 2007).

\section{MATERIALS AND METHODS}

This study uses quantitative method for data collection, due to the large number of respondents and wide geographical coverage. Furthermore, this study uses farmers of the Southern Region of Iraq who are users of mobile phones. This region was selected because it is stable of civil conflicts rather than north and middle regions are unstable regions as well as the Southern Region is the first region in Iraq that implemented e-Government services. In addition, the total number of participants was 350 and only 250 responses were valid. For data collection from Federations of Farm Associations (FFAs) Southern Region. Table 1 shows the number of federations of farm associations and farmers in Southern Region of Iraq.The survey method was adopted for data collection by using the questionnaire. The
Table 1: No. of Federations of Farm Associations and Farmers in Southern Region of Iraq

\begin{tabular}{lrcc}
\hline $\begin{array}{l}\text { Name of Federation } \\
\text { of Farm }\end{array}$ & $\begin{array}{l}\text { No. of } \\
\text { farmers } \\
\text { in FFA }\end{array}$ & $\begin{array}{l}\text { Sampling } \\
\text { of }(\%)\end{array}$ & $\begin{array}{c}\text { Probability } \\
\text { sampling of } \\
\text { farmers }\end{array}$ \\
\hline FFA in Dhi-Qar & 18445 & 54 & 189 \\
FFA in Basrah & 9434 & 28 & 97 \\
FFA in Al-Muthanna & 5220 & 15 & 53 \\
FFA in Maysan & 1026 & 3 & 11 \\
The Total & 34125 & 100 & 35 \\
\hline
\end{tabular}

convenience sample approach was used for getting the information regarding use of internet on mobile phones. Main purpose of use of mobile phones and mobile phones saved time and money. The SPSS 21 Version was used for data analysis of this study.

\section{RESULTS AND DISCUSSION}

Considering the gender of the respondents as shown in Table 2, The result showed that 250 male respondents participated in this study. The rural society of Iraq is reflected through these findings. In rural society, there are differences between male and female as a result of traditions and habits that are prevailed in rural areas where the responsibility of women is to focus on managing the child-raising and home related works. Furthermore, the findings revealed that out of 250 respondents, 135 of the respondent's age were $26-30$ years old which equals to $54 \%$ whereas $25.2 \%$ age was $31-35$ years. Moreover, when asked the respondents about their marital status the result showed that $83.6 \%$ of the respondents were married and $16.4 \%$ of the respondents were single. Furthermore, in terms of educational level, findings revealed that 46 of 250 of respondents which equal to $18.4 \%$ had non-formal education level, however, 73 of 250 of respondents which equal to $29.4 \%$ had primary education level and 66 of the respondents $(26.4 \%)$ was matriculation whereas 36 of them which equal to $14.4 \%$ had intermediate education level while 29 of the respondents $(11.6 \%)$ were bachelor education. Furthermore, the respondents were asked about their monthly income, the result showed that 167 of the respondents which equal to $70.4 \%$ had $251-500$ thousand (Iraqi Dinar per month) in month whereas 51 of the respondents which equal to $20.4 \%$ had $1-250$ thousand (Iraqi Dinar per month) in month (refer Table 2).

Based on asked the respondents about own mobile phones as shown in Table 3 the result revealed 234 of 250 respondents which equal to $93.6 \%$ of the respondents were their own mobile phones while $16(6.4 \%)$ of the 
J. Eng. Applied Sci., 14 (Special Issue 2): 5495-5500, 2019

Table 2: Demographic profile of respondents

\begin{tabular}{lrc}
\hline $\begin{array}{l}\text { Demographic } \\
\text { Variables/Categories }\end{array}$ & $\begin{array}{r}(\mathrm{N}=396) \\
\text { frequency }\end{array}$ & Percentage \\
\hline Gender & & \\
Male & 250 & 100 \\
Age & & \\
$20-25$ & 33 & 13.2 \\
$26-30$ & 135 & 54 \\
$31-35$ & 63 & 25.2 \\
36-40 & 19 & 7.6 \\
Total & 250 & 100 \\
Marital status & & \\
Single & 41 & 16.4 \\
Married & 209 & 83.6 \\
Total & 250 & 100 \\
Education level & & \\
Non formal education & 46 & 18.4 \\
Primary & 73 & 29.2 \\
Matric & 66 & 26.4 \\
Intermediate & 36 & 14.4 \\
Bachelor & 29 & 11.6 \\
Total & 250 & 100 \\
Monthly income & & \\
1-250 Thou. (ID) & 51 & 20.4 \\
251-500 Thou. (ID) & 176 & 70.4 \\
501-750 Thou. (ID) & 23 & 9.2 \\
Total & 250 & 100 \\
\hline
\end{tabular}

respondents have no mobile phones. In addition, the respondents were asked about the purpose of the use of mobile phones as shown in Table 3 , the result showed that 200 of respondents which equal $80 \%$ said that the main aim of use of mobile phones was to contact with their friends whereas $13.6 \%$ said they communicate with their family and only $6.4 \%$ of the them said that they use weather applications or talk with department of metrological to get the information about weather. The respondents were also, inquired about the benefit of the mobile phones the result revealed that 228 of respondents which equal to $91.2 \%$ said that mobile phones have given a good benefit such they can easily contact with each other without any obstacle also, get information about weather and usage of pesticides in crops.

Moreover, the contact with Federations of Farm Associations or agriculture officer about agriculture problems which are faced them was assessed in this study. Based on the results as shown in Table 3, the 239 of the respondents which equal to $95.6 \%$ did not communicate with Federations of farm associations or agriculture officer about agriculture problems in their field it was showed that most of the farmers are using traditional method to contact with agriculture officer and were not interested to adopt new technologies on their works. However, the result revealed that only $4.4 \%$ of the respondents were contact with agriculture officer regarding agriculture issues and problems in their field. It showed that the farmers who were more educated were
Table 3: Main purpose of use of mobile phones

\begin{tabular}{lrr}
\hline Variables & Frequency & Percentage \\
\hline Do you have mobile phone & & \\
Yes & 234 & 93.6 \\
No & 16 & 6.4 \\
Total & 250 & 100 \\
What is your main purp ose & & \\
to use mobile & 200 & \\
contact with friends & 34 & 80 \\
contact with family & 16 & 6.4 \\
contact with metrological department & 250 & 100 \\
Total & & \\
Do you understand that mobile & & \\
phones given benefit & 228 & 91.2 \\
Yes & 22 & 8.8 \\
No & 250 & 100 \\
Total & & \\
Do you contact with agriculture & & \\
officer by phone & 11 & 4.4 \\
Yes & 239 & 95.6 \\
No & 250 & 100 \\
Total & &
\end{tabular}

aware about the benefit of this technology and were communicated with Federations of Farm Associations or agriculture officers for getting the update of weather as well as diseases of agriculture and use of pesticides in their farms as shown in Table 3.

The respondents were inquired their opinions about the increase their income by use of mobile phone. the result indicated that 197 of respondents which equal to $78.8 \%$ reported that mobile phones did not increase their income. It revealed that most of the farmers use mobile phone only contact with their family and friends but they did not communicate with any Federations of Farm Associations or agriculture officers for getting information about weather, diseases of agriculture and use of pesticides in their farms. However, few farmers (20.4\%) whose education level was good to communicate with Federations of Farm Associations or agriculture officers.

The respondents were asked about the mobile phone made their life easy the result showed that $209(83.6 \%)$ of respondents reported that mobile phone has made their life easy. There is no doubt that mobile phones have efficient role to make the life very easy, through communicate and discuss and share information with each other's.

Furthermore, the respondents were investigated about mobile phones saved, money, energy and time the result showed that $220(88 \%)$ of the respondents said that they have saved their time, money and energy by using of mobile phones. While $30(12 \%)$ of the respondents indicated that the mobile phones did not save their time, money and energy as shown in Table 4.

Based on the results as shown in Table 5 the respondents were explored regarding the use of internet on mobile phones, the result revealed that 211 of respondents which equal to $84.4 \%$ are used internet on 
J. Eng. Applied Sci., 14 (Special Issue 2): 5495-5500, 2019

\begin{tabular}{lrc}
\multicolumn{3}{l}{ Table 4: Mobile phones saved time and money } \\
Variables & Frequency & Percentage \\
\hline Mobile have increased your income & & \\
Yes & 51 & 20.4 \\
No & 197 & 78.8 \\
Some time & 2 & 0.8 \\
Total & 250 & 100 \\
Mobile phone made easy & & \\
your life & 209 & \\
Yes & 41 & 83.6 \\
No & 250 & 16.4 \\
Total & & 100 \\
Mobile have saved your money, & & \\
energy and time & 220 & 88 \\
Yes & 30 & 12 \\
No & 250 & 100 \\
Total & & \\
&
\end{tabular}

mobile phones. The result implied that the respondents who have education not high also, using the internet on mobile phone and search different things for their entertainment (such as read the online newspapers, magazines and games online). However, $39(15.6 \%)$ of the respondents did not use internet by mobile phones. This result showed that the respondents who have non formal education and no any information and knowledge about using internet. They used mobile phones only to communicate with friends and family.

Furthermore, the respondents were examined about using social media on mobile phones; the result showed that 154 of respondents which equal to $61.6 \%$ are used Facebook on internet by mobile phone. This implied that most the respondents whose education level was more than matric were using the Facebook on mobile phone and communicates with their friends. Whereas $4 \%$ of them were used Twitter, these were whose education level was bachelor level. Furthermore, 92 (36.8\%) of the respondents were used social media and other websites on internet. The respondents were asked about search of weather information on internet by mobile, the result revealed that $235(94 \%)$ of the respondents did not search any weather information on internet by mobile phone.

In clearly, the results revealed that most of the respondents were insensible about the use of internet properly on mobile phone only just they are use social media websites (especially, Facebook use). Moreover, the results showed that only $6 \%$ of the respondents search some time weather information on internet through mobile phone. The respondents who have education was high some time use internet on mobile devices to search the weather information. However, most of the respondents have not information that how to search on internet about the weather information. While the respondents were asked about the searching the information regarding agricultural information on internet by mobile phone, the
Table 5: Internet use on mobile phone

\begin{tabular}{lrr}
\hline Variables & Frequency & Percentage \\
\hline Internet on mobile phone & 211 & \\
Yes & 39 & 84.4 \\
No & 250 & 15.6 \\
Total & & 100 \\
Use social media by mobile & 154 & \\
Facebook & 0 & 61.6 \\
LinkedIn & 4 & 0 \\
Twitter & 92 & 1.6 \\
Others & 250 & 36.8 \\
Total & & 100 \\
Search weather information by mobile & 15 & \\
Yes & 235 & 6 \\
No & 250 & 94 \\
Total & & 100 \\
Agricultural information by mobile phone & \\
Yes & 8 & 3.2 \\
No & 240 & 96 \\
Some time & 2 & 0.8 \\
Total & 250 & 100 \\
\hline
\end{tabular}

result revealed that $240(96 \%)$ of the respondent did not search information about agricultural regarding the diseases of agriculture and use of pesticides in their farms. While only $3.2 \%$ of the respondents search information about agriculture it explored that the respondents who have education were high concerned to get the information about agriculture and only $0.8 \%$ of the respondents some time search the information regarding agriculture as shown on Table 5).

\section{CONCLUSION}

In different developing countries Information and Communication Technologies (ICTs) as instruments of socialization and information have improve the economy and living level of people and different societies are getting benefit from these communication technologies. Hence, ICTs have become one of the fundamental building blocks of modern communities. But in the perspective of the Iraq, the findings revealed that farmers are not using these technologies for agriculture development. Also, result clearly showed that farmers did not use mobile phones for communicating with agriculture and customers but only contact with their family and friends. If farmers communicate with agriculture officers and customers they can increase their income as well as contribute in economic development of the country. However, there is need to provide trainings and increase their education than it can give a positive results in agriculture development of the country.

\section{REFERENCES}

Amos, W., 2011. Exploring m-Government readiness: The case of Vanuatu. Master Thesis, Auckland University of Technology, New Zealand. 
Aqilah, A.R., 2011. Cultural factors in a mobile phone adoption and usage model: A case of UUM postgraduate students. Master Thesis, Universiti Utara Malaysia, Changlun, Malaysia.

Bhavnani, A., R.W.W. Chiu, S. Janakiram and P. Silarszky, 2008. ICT policy division Global Information and Communications Department (GICT): The role of mobile phones in sustainable rural poverty reduction. MSc Thesis, The World Bank, Washington, DC., USA.

Chatterjee, S., S. Chakraborty, S. Sarker, S. Sarker and F.Y. Lau, 2009. Examining the success factors for mobile work in healthcare: A deductive study. Decis. Support Syst., 46: 620-633.

Chhachhar, A.R. and M.S. Hassan, 2013. The use of mobile phone among farmers for agriculture development. Article Intl. J. Sci. Res., 2: 95-98.

Chhachhar, A.R., B. Qureshi, G.M. Khushk and Z.A. Maher, 2014. Use of mobile phone among farmers for agriculture information. Eur. J. Sci. Res., 119: 265-271.

Garnett, J.L., J. Marlowe and S.K. Pandey, 2008. Penetrating the performance predicament: communication as a mediator or moderator of organisational culture's impact on public organisational performance. Public Admin. Rev., 68: 266-281.

Gichamba, A. and I.A. Lukandu, 2012. A model for designing m-Agriculture applications for dairy farming. Afr. J. Inf. Syst., 4: 120-136.

Glood, S.H., W.R.S. Osman and M.M. Nadzir, 2016. The effect of civil conflicts and net benefits on m-Government success of developing countries: A case study of Iraq. J. Theor. Appl. Inf. Technol., 88: 541-552.

ITU. and OECD., 2011. Towards the Next Generation of Public Services. In: m-Government: Mobile Technology for Responsive Governments and Connected Societies, OECD. (Ed.). OECD Publishing, Paris, France, ISBN:9789264118690, pp: 15-24.
ITU., 2018. Statistics. International Telecommunication Union, Geneva, Switzerland. https://www.itu.int/ en/ITU-D/Statistics/Pages/stat/default.aspx

Kamil, A.K., 2012. Arab ict use and social networks adoption. King Abdulaziz City for Science and Technology, Riyadh, Saudi Arabia. https://www. wamda.com/2012/12/ict-use-and-social-network-ad option-in-the-arab-region-report

Melkers, J. and K. Willoughby, 2005. Models of performance-measurement used in local governments: Understanding budgeting, communication and lasting effects. Public Admin. Rev., 65: 180-190.

Mengistu, D., H. Zo and J.J. Rho, 2009. m-Government: Opportunities and challenges to deliver mobile government services in developing countries. Proceedings of the 4th International Conference on Computer Sciences and Convergence Information Technology, November 24-26, 2009, Seoul, South Korea, pp: 1445-1450.

Munyua, H., 2007. ICTs and small-scale agriculture in Africa: A scoping study. Master Thesis, Food and Agriculture Organization, Rome, Italy.

Nassuora, A.B.A., 2010. Mobile phone technology knowledge sharing model among university academics. Ph.D Thesis, Universiti Utara Malaysia, Changlun, Malaysia.

Pandey, S.K. and J.L. Garnett, 2006. Exploring public sector communication performance: Testing a model and drawing implications. Public Administration Rev., 66: 37-51.

Raja, S., S. Melhem, M. Cruse, K. Maher and M. Minges, et al., 2012. Making Government Mobile. In: Information and Communications for Development Maximizing Mobiles, The World Bank (Ed.). The World Bank, Washington, USA., ISBN: 9780821389911, pp: 87-101.

Younus, A.D., 2014. Investigation of a mobile government a case study in Iraq. Master Thesis, Near East University, Nicosia, Cyprus. 